\title{
Effect of Moisture Content on the Grinding Process and Powder Properties in Food: A Review
}

\author{
Hwabin Jung, Youn Ju Lee and Won Byong Yoon * \\ Department of Food Science and Biotechnology, College of Agriculture and Life Sciences, Kangwon National \\ University, Kangwondaehak-gil, Chuncheon, Gangwon 24341, Korea; hwabinj@gmail.com (H.J.); \\ skiee13468@gmail.com (Y.J.L.) \\ * Correspondence: wbyoon@kangwon.ac.kr; Tel.: +82-33-241-0508
}

Received: 28 April 2018; Accepted: 21 May 2018; Published: 1 June 2018

\begin{abstract}
Grinding is a staple size-reduction process to produce food powders in which the powdered form is chemically and microbiologically stable and convenient to use as end products or intermediate products. The moisture content of food materials before grinding is a particularly important factor, since it determines the materials' physical properties and the powder properties, such as flowability after grinding. Generally, the moisture content of food materials is closely related to its energy requirement for grinding, because the energy expenditure required to create new surfaces varies. Grinding models used to analyze and predict the grinding characteristics, including energy, have been developed in many studies. The moisture content also influences powder flow properties. The inter-particle liquid bridges among the particles are due to the moisture in powders; therefore, the flowability of powders is interrupted because of the increase of the cohesiveness of the powder. Understanding the grinding characteristics related to various moisture contents is, theoretically and experimentally, an important cornerstone in optimizing the grinding processes used in food industries. In this review, comprehensive research of the effect of moisture content on the grinding process and powder properties is presented.
\end{abstract}

Keywords: grinding; moisture content; grinding characteristics; grinding modeling; powder flowability

\section{Introduction}

The grinding process, a unit operation to reduce the size of material, plays a major role in many aspects in the food industry. Many food processes frequently require size reduction, which is accomplished by applying diverse forces to create particles with certain sizes and shapes. Size reduction, directly linked to chemical and microbiological stability and convenience, is one of the most cardinal and energy consuming processes in the food industry. In the food industry, powders are considered as both end products and intermediate products between unit operations [1]. The grinding process involves a variety of operations using equipment such as mincer, crushers, cutters, mills, grinders, shredders, disintegrators and homogenizers [2,3]. Grinding requires the breaking or tearing of the materials by such mechanisms as compression, impact, attrition or shear and cutting [4]. Solid food materials are broken down into a large number of fine particles by size-reduction mechanisms. Powders, then, are produced by grinding.

Many parameters involved in the grinding process and related to the material, such as the grinding method and machinery, grinding time, and the strength and moisture content of the material, affect the powder characteristics. The amount of moisture in food materials before grinding is a particularly important factor because it helps determine the materials' physical properties and the powder properties [5]. Many researchers have investigated the efficiency of the grinding process as applied to grains and other food materials with various moisture contents [3,6-10]. Several studies 
have shown that the particle properties depend on the structure of food materials, which might be different at various levels of moisture content $[3,10,11]$. In addition, the mass fraction of coarse particles is smaller for those with a lower moisture content than for those with high moisture levels, and vice versa $[9,10]$. The fact that the coarser particles generally have less sphericity is closely related to the internal friction between particles. Especially, the powder flow properties are significantly influenced by the irregular shapes in coarse particles [11,12]. Thus, the powders from the food materials with different levels of moisture content could show different powder properties with regard to such issues as shapes of particles, particle size distribution, and flowability-which is the ability of a powder to flow.

Grinding is an energy intensive process in which a hard matter is broken down. The consumption of energy for reducing the size of numerous types of agricultural and food materials increases when the size of the screen opening changes from coarser to finer and when an increase is present in the moisture content or material hardness [13]. The requirements in energy consumption in grinding increases as the moisture level in the material becomes higher. This is due to higher moisture contents that make the process of deforming and cutting the material more intensive $[7,9,14]$. Therefore, the grinding energy has to be analyzed to reduce inefficient energy consumption. Several models, such as Rittinger [15], Kick [15] and Bond [16], have explained the consumption of energy during the process of grinding food and agricultural material.

The properties of powders play a cardinal role in processing or handling operations, such as formulation and mixing, storage in hoppers and silos, compression and packaging, and transportation [17-19]. The cohesiveness of powders is associated with the moisture content due to the inter-particle liquid bridges, which cause the spontaneous agglomeration of particles. It is important for the powder to exhibit properties that allow it to flow easily, in a fluid-like manner, so that the materials can be handled without serious limitations, such as cohesiveness, friction, and the interlocking of particles. The design of efficient powder handling processes requires the measurement of powder flow properties. Flowability comprises the particle properties (i.e., size and shape) by grinding, grinding energy consumption and models, as well as powder flowability depending on the moisture content. Generally, flow properties of powders are determined by a shearing test based on the Jenike shear cell test $[10-12,18,20,21]$. Recently, many novel methods to optimize the flow patterns of powders in the handling processes have been reported, such as simulations with a discrete element method (DEM) [22], rheological measurements [23], and image analysis using a computer [24,25].

The primary objective of this review is to provide an overview of the effects of moisture content on grinding processes and powder properties. This review includes the mathematical models to describe the grinding efficiency in terms of size reduction and the energy consumption, and the flowability with respect to the moisture content of food and agricultural materials. Additionally, the traditional and novel methods are discussed.

\section{Influence of Moisture Content on the Grinding Process}

Grinding is accomplished by exerting mechanical stress on a material followed by its rupture, and the energy this process requires depends upon the friability of the material. In the grinding process, the initial moisture content affects the material's mechanical properties, such as strength, stiffness, elasticity and plasticity [6,26-28]. The grinding time and energy consumption are determined by these mechanical properties of the food materials, as are the appearance and characteristics of the final ground product [29]. Generally, the efficiency of the food grinding process increases as the moisture content of the material decreases because material with less moisture is more brittle $[6,9,30]$. The increasing plasticity or ductility of the materials containing a high amount of moisture is responsible for the increase in the energy consumption during grinding. Therefore, dry or wet grinding methods, in which the initial moisture content is adjusted before grinding, have been employed in commercial grinding processes to investigate the effect of moisture content on the grinding efficiency [5]. These grinding processes with various grinding machines affect the compositions, the distribution 
of particle size, and quality of the end product of the food materials. In addition, modeling of the grinding process has been studied and reported in the literature. This modeling studies addressed what is known as the dynamic principle which utilizes the first-order reaction kinetics based on the kinetic behavior of particle size reduction, as well as grinding characteristics, with the aim of prediction, optimization, and analysis of the grinding process. In the following subsections, the effects of moisture content on grinding characteristics, grinding models of powder characteristics and energy consumption, grinding methods for food materials, and the particle shape and size distribution of the end product are discussed in detail.

\subsection{The Influence of Moisture Content on the Grinding Characteristics}

For many food materials, the initial moisture content is the most cardinal variable determining the size distribution of particles and the grinding time. Thus, controlling the moisture content with such pretreatments as drying or adding moisture is imperative before grinding. An overview of papers on the effects of the moisture content on the grinding process of cereals, legumes, vegetables and fruits is represented in Table 1. 
Table 1. Overview of research reports on the grinding of food materials with initial moisture adjustment.

\begin{tabular}{|c|c|c|c|c|c|}
\hline Materials & Range of Moisture Content & Grinding Method & Grinder & Grinding Properties Influenced by Moisture Content & References \\
\hline Balloon flower & $8-20 \%$ & Dry grinding & Domestic grinder & $\begin{array}{ll}- & \text { Average particle size } \\
- & \text { Grinding energy }\end{array}$ & [10] \\
\hline Barley & $10-14 \%$ & Dry grinding & Roller mill, impact mill & - Product yield & [31] \\
\hline Black pepper & $5.5-17.6 \%$ (d.b.) & Dry grinding & Micro pulverizer-hammer mill & $\begin{array}{ll}- & \text { Milling losses } \\
- & \text { Specific energy consumption } \\
- & \text { Mass fractions retained on sieves } \\
- & \text { Size reduction ratio } \\
- & \text { Grinding effectiveness } \\
- & \text { Grinding energy }\end{array}$ & [32] \\
\hline Black soybean & $4-20 \%$ & Dry grinding & Domestic grinder & $\begin{array}{ll}\text { - } & \text { Average particle size } \\
\text { - } & \text { Grinding energy }\end{array}$ & [14] \\
\hline Corn & $10-18 \%$ (w.b.) & Dry grinding & Hammer mill & $\begin{array}{ll}- & \text { Specific energy consumption } \\
- & \text { Degree of fineness } \\
- & \text { Size reduction ratio } \\
- & \text { Mean weight diameter } \\
- & \text { Grinding ability index } \\
- & \text { Grinding effectiveness }\end{array}$ & [33] \\
\hline Corn & $10.39-19.64 \%$ (w.b.) & Dry grinding & Hammer mill & $\begin{array}{ll}- & \text { Specific grinding energy } \\
\text { - } & \text { Particle size distribution }\end{array}$ & [34] \\
\hline Durum wheat & $9-15 \%$ & Dry grinding & Ultracentrifugal mill & $\begin{array}{ll}\text { - } & \text { Average particle size } \\
\text { Particle size distribution }\end{array}$ & [35] \\
\hline Fenugreek seed & $5.1-17.3 \%$ (d.b.) & Dry grinding & Micro-pulverizer-hammer mill & $\begin{array}{ll}- & \text { Average particle size } \\
- & \text { Milling losses } \\
- & \text { Specific energy consumption } \\
- & \text { Size reduction ratio } \\
- & \text { Grinding effectiveness } \\
- & \text { Grinding energy }\end{array}$ & [36] \\
\hline Flaxseed & $5.5-10.5 \%$ & Dry grinding & Centrifugal cutting mill, hammer mill & - Means of fine-particle yield & [37] \\
\hline Horse bean, pea, lupine, vetch & $10-18 \%$ & Dry grinding & Hammer mill & - Grinding energy requirements & [30] \\
\hline Maize (corn) & $30-42 \%$ (w.b.) & Dry grinding & Disc attrition mill & Particle size distribution & [38] \\
\hline Maize (corn) & $9.6-32.5 \%$ (d.b.) & Dry grinding & Hammer mill & $\begin{array}{ll}- & \text { Grinding energy } \\
- & \text { Final particle size }\end{array}$ & [39] \\
\hline Mango & $12.83-17.75 \%$ & Dry grinding & Domestic grinder & - Particle size distribution & [3] \\
\hline Pea & $4.5-17 \%$ & Dry grinding & Classifier mill & Energy consumption for grinding & [40] \\
\hline
\end{tabular}


Table 1. Cont.

\begin{tabular}{|c|c|c|c|c|c|}
\hline Materials & Range of Moisture Content & Grinding Method & Grinder & Grinding Properties Influenced by Moisture Content & References \\
\hline Pearl millet & $6.2-12.3 \%$ (d.b.) & Dry grinding & Hammer mill & $\begin{array}{ll}- & \text { Milling loss } \\
- & \text { Particle weight fraction } \\
- & \text { Water absorption capacity of powder } \\
- & \text { Grinding energy }\end{array}$ & [41] \\
\hline Popped gorgon nut & $6.2-12.3 \%$ (d.b.) & Dry grinding & Hammer mill & $\begin{array}{ll}- & \text { Particle weight fraction } \\
- & \text { Water absorption capacity of powder } \\
\text { - } & \text { Grinding energy }\end{array}$ & [42] \\
\hline Quince & $10-14 \%$ (w.b.) & Dry grinding & Hammer mill & $\begin{array}{ll}- & \text { Average particle size } \\
- & \text { Specific grinding energy } \\
- & \text { Particle size distribution }\end{array}$ & [43] \\
\hline Quinoa & $10-14 \%$ (w.b.) & Dry grinding & Roller mill & $\begin{array}{ll}- & \text { Particle size distribution } \\
- & \text { Average particle size } \\
- & \text { Specific grinding energy }\end{array}$ & [44] \\
\hline Rice & $13-32 \%$ & Wet grinding & Hammer mill & - Average particle size & [45] \\
\hline Sorghum & $12-20 \%$ & Dry, Semi-wet grinding & Abrasive decortication, Roller mill & - Product yield & [46] \\
\hline Soybean & $6-12 \%$ & Dry grinding & Domestic grinder & $\begin{array}{ll}\text { - } & \text { Average particle size } \\
\text { - } & \text { Grinding energy }\end{array}$ & [9] \\
\hline Soybean & $12-154 \%$ (d.b.) & Wet grinding & Domestic chopper & $\begin{array}{l}\text { Amount of remaining solids on screens } \\
\text { (product yield) }\end{array}$ & [26] \\
\hline Triticale & $11-15 \%$ & Dry grinding & Disc mill, hammer mill & - Milling yield & [47] \\
\hline Wheat & $7.29-15.6 \%$ & Dry grinding & Automatic laboratory mill, disc mill & Mean particle size, particle size distribution & [48] \\
\hline Wheat & $10-20 \%$ (d.b.) & Dry grinding & Hammer mill & $\begin{array}{ll}- & \text { Average particle size } \\
- & \text { Mass fraction of particles } \\
- & \text { Specific grinding energy }\end{array}$ & [27] \\
\hline Wheat & $10-20 \%$ (w.b.) & Dry grinding & Roller mill & $\begin{array}{ll}- & \text { Particle size distribution } \\
- & \text { Average particle size } \\
\text { - } & \text { Grinding energy }\end{array}$ & [8] \\
\hline Wheat & $8.9-16.3 \%$ & Dry grinding & Roller mill & - $\quad$ Particle size distribution & [49] \\
\hline Wheat & 6.7-11.1\% (d.b.) & Dry grinding & Domestic grinder & - Grinding energy & [6] \\
\hline Yam & $8-24 \%$ (w.b.) & Dry grinding & Disc mill & Flour fraction (product yield) & [50] \\
\hline
\end{tabular}


The initial moisture content influenced such grinding properties as average particle size, particle size distribution, grinding energy, product yield, grinding loss, etc. In most grinding results, materials with high moisture content had larger average particle sizes and higher grinding energy consumption than the powder produced by low moisture materials, because foods with high moisture content became difficult to grind since water acts as a plasticizer $[9,10,14,35,36,43,44]$. The water made the materials soft, so that they resisted the size reduction during the grinding process. Thus, the more brittle materials, with lower moisture content, were more easily broken and powdered. In contrast, rice [45] and wheat $[8,27]$ showed the opposite result. Wet grinding and grinding of soft materials produce finer powders due to the softening effect of water. For this reason, ground rice and soft wheat had significantly smaller particle sizes due to their higher moisture content.

For the dry grinding of barley, flaxseed, sorghum, triticale and yam, the product yield also decreased due to the higher moisture content of the materials. However, Pan and Tangratanavalee [26] described a different effect of the moisture content on the grinding process of soybean when the moisture content in the bean is very high, such as $154 \%$ (d.b.). Usually, moisture content had a different effect on a wet grinding method than a dry grinding method. In dry grinding, the mechanical strength (i.e., a tensile strength) of the seed coat is cardinal in determining the grinding efficiency [9]. However, when grains were subjected to a soaking process, the moisture content in the seed coat increased substantially, and it eventually lost its resistance to the rupture force. In wet grinding, the grinding efficiency is mainly determined by the softness of cotyledon. The higher moisture content in the bean changed the softer tissues, and that increased the grinding efficiency during wet grinding.

Consequentially, it is important that the moisture content be adjusted so that the quality of the powder is maintained due to the fact that the cost of the grinding process depends upon the moisture content of food samples. In addition, with an increase of the moisture content, the mass fraction of coarse particles and the average particle size increased in many food materials, such as wheat [48], maize [39], mango [3], soybean [9] and balloon flower [10] due to decrease of brittleness of materials.

The grinding ability has been determined based on the dynamic principle laid down by Djantou et al. [3]. The plot of yield of a specific particle size as a function of time for grinding is presented as a sigmoidal curve, which is due to the fact that the grinding yield generally reaches an equilibrium level as the grinding time increases. The maximum grinding yield of a certain size particle $i$, the grinding ability constant, and the time needed to obtain $50 \%$ of the mass of initial materials with a specific particle size could be derived by the following grinding mechanism:

$$
M+M_{G i} \stackrel{k}{\rightarrow} 2 M_{G i}
$$

where $M$ is the quantity of material at the initial state, $k$ is the grinding constant, and $M_{G i}$ is the quantity of ground material penetrating through a specific sieve of diameter $(i)$ at a given grinding time. Several modeling studies on the grinding of food materials with various levels of moisture content have been carried out. For example, a negative correlation has been found between the moisture content of mango and the maximum grinding yield and the grinding ability in the study of [3]. A shorter caking time (i.e., time to form the agglomerate due to the stickiness of the particles) was observed in the sample with the highest moisture content, which may correspond to the sugar content of dried mango. In a study of the grinding kinetics of soybean [9], as the moisture content in the bean decreased, the maximum grinding yield and the grinding ability increased. The caking phenomenon was not observed in the case of the soybeans; however, the agglomeration occurred with a particle size finer than $0.15 \mathrm{~mm}$ at a $12 \%$ moisture content (Figure 1). According to Moon and Yoon [10], as the moisture content of balloon flower lessened, the maximum grinding yield increased. They showed that the grinding efficiency was higher at a low moisture content than the other. Particle agglomeration and caking phenomena were not observed in that study. For the grinding study of black soybeans [14], the grinding ability of the particles with small sizes $(<0.25 \mathrm{~mm})$ decreased with the decrease of moisture content, whereas the grinding ability of the particles with large sizes $(>0.43 \mathrm{~mm})$ increased. 

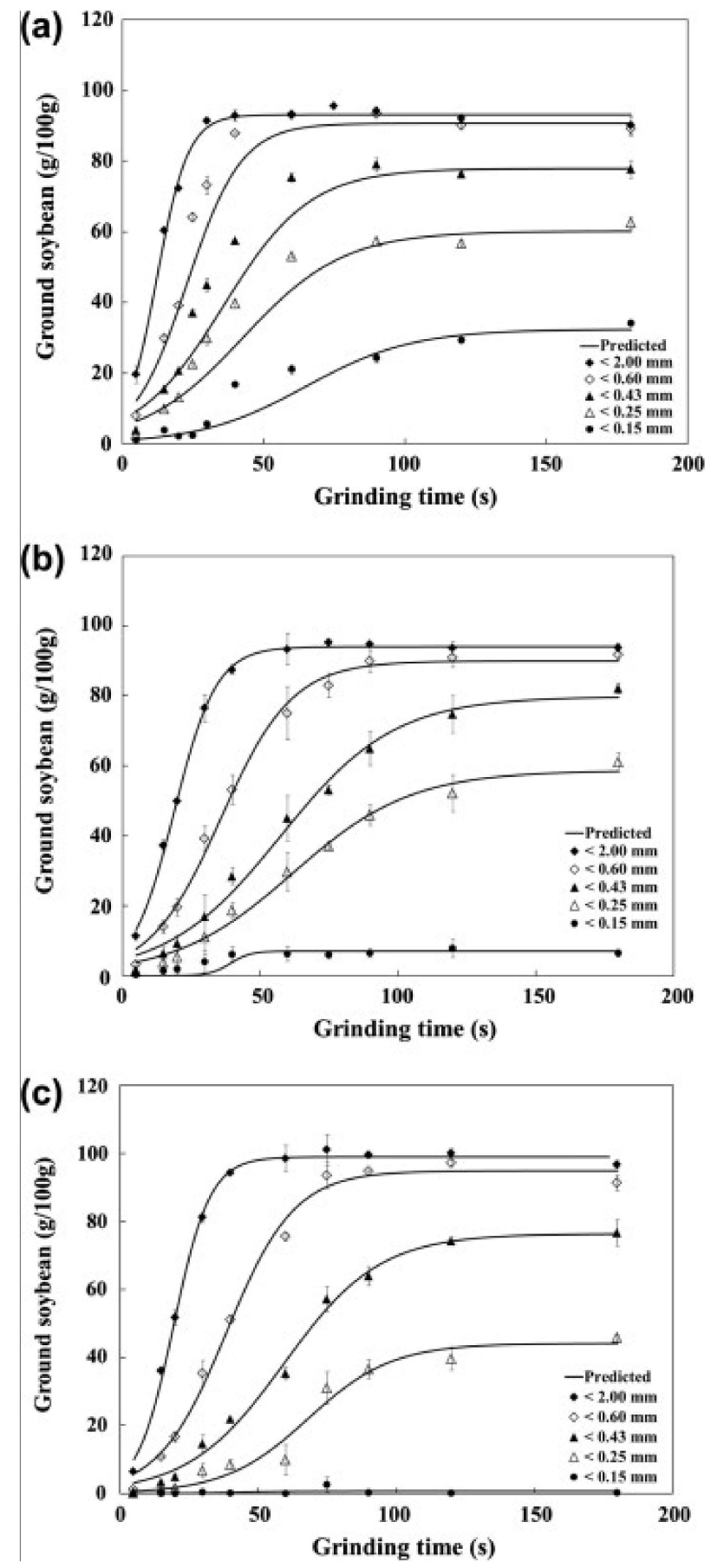

Figure 1. The dynamic principle grinding kinetics of soybean grinding with different initial moisture content; (a) $6 \%$, (b) $8 \%$ and (c) $12 \%$ (Lee et al. [9], with permission).

\subsection{Grinding Energy}

Moisture content of the food materials can greatly affect the grinding energy expenditure and the degree of the reduction of material's particle size. The energy is the most costly component in the grinding process, so the variables associated to the energy consumption need to be accurately controlled. During the grinding process, at first the particles are distorted within their elastic limits [4]. Subsequently, additional force is applied to the stressed particles, which results in the particles being ruptured into fragments. When the mechanical energy is supplied to the particles, some of the energy 
is used to create new surfaces while the rest of the energy is dissipated to heat according to the energy conservation [51]. Generally, it is favorable to dehydrate solids that are brittle prior to grinding because of the brittle materials break without plastic deformation, which consumes a lot of energy $[6,8,27,39,40]$. The energy-size reduction principles were formulated for designing the grinding operation and predicting the performance of a grinding process by Kick, Rittinger and Bond. The following equations (Equations (2)-(5)) to determine Bond's (work index), Kick's and Rittinger's constants are based on the initial and final particle sizes:

Bond's law:

$$
\mathrm{E}=K_{b}\left[\frac{1}{\sqrt{L_{2}}}-\frac{1}{\sqrt{L_{1}}}\right]
$$

Bond's work index:

$$
W_{\text {ind }}=\frac{K_{b}}{0.3162}
$$

Kick's law:

$$
\mathrm{E}=K_{k} \ln \left[\frac{L_{1}}{L_{2}}\right]
$$

Rittinger's law:

$$
\mathrm{E}=K_{r}\left[\frac{1}{L_{2}}-\frac{1}{L_{1}}\right]
$$

where $\mathrm{E}$ is the energy requirement for grinding, $L_{1}$ and $L_{2}$ are the mean diameters of the initial and final ground particle size of samples, respectively, and $K_{b}, K_{k}$ and $K_{r}$ are the Bond's, Kick's and Rittinger's constants, respectively. The work index is represented as $W_{\text {ind }}$ that is defined as the energy requirement for grinding bulky particles to a size that can penetrate through a $100 \mu \mathrm{m}$ sieve [51].

The grinding "laws" can be applied to evaluate efficiency of the grinding of food materials with varied levels of moisture content. Generally, at the high moisture content, the grinding energy also has been found $[9,27,33]$ to be increased due to the fact that the plasticity of the food materials increased. On the other hand, the food materials with low moisture content are brittle and easy to grind, thus the dried samples need less energy for grinding. According to Walde et al. [6], as the drying time using microwave increased, the energy efficiency in grinding (i.e., the reduction of grinding energy) was observed. In addition, Djantou et al. [3] described how the high moisture content caused a rise in the grinding energy needed for the powder production of dried mango. They have showed that a positive correlation between the water content of mango and the grinding characteristics including grinding constants $\left(K_{b}, K_{k}\right.$ and $\left.K_{r}\right)$ and the work index $\left(W_{i n d}\right)$. In the studies of Lee and Yoon [9] and Lee et al. [14], soybeans and black soybeans with less moisture contents resulted in lower values of the grinding constants associated in the grinding law models and a decrease in the energy requirement. The results of the research into balloon flower with various levels of moisture content was similar to results of research into soybeans and black soybeans [10]. These studies concluded that the brittle samples with low moisture content required less energy for grinding. Therefore, the grinding process has to be designed with a view to controlling the moisture content of food materials to minimize the energy requirements.

\subsection{Grinding Methods for Food Materials}

Grinding methods and grinding machinery are major operational factors that control the powder properties with certain initial moisture content of food materials. There are three methods used to prepare food powder by adjusting moisture content: dry grinding, semi-dry/wet grinding and wet grinding [45]. Dry grinding is conducted without water and with a low consumption of grinding energy. On the other hand, wet grinding uses excess water, which is directly linked to loss of powder, high water consumption, high energy consumption and treatment of wastewater. The powder properties, such as structures, viscosity and particle size, could be controlled by implementing the semi-dry/wet grinding process because the intermediate properties can be found [5]. Grinding operations using the 
three grinding methods and various grinding machines lead to different grinding result, i.e., particle size, composition, functional properties, and product quality using the powder. On the other hand, the inherent structure of food materials, applied grinding power, and grinding technology also contribute to the grinding properties, but this will not be addressed in this bibliographical study which concerns the moisture content.

\subsubsection{Dry and Semi-Dry/Wet Grinding}

Dry and semi-dry/wet grinding are common methods that do not add excess water during grinding, do not produce waste water, and thus, consume lesser amounts of energy during grinding. The sample for dry grinding is usually used as is or dried, and for semi-dry/wet grinding includes previous soaking and draining process. Generally, these are the three methods used in most grinding processes of food materials. Grinding machines used in the dry grinding method include a pin mill, hammer mill, disc mill, roller mill, etc. The semi-dry/wet grinding process also uses dry grinding machinery. Dry and semi-dry/wet grinding methods have been carried out to investigate the effect of moisture content on grinding cereals $[6,8,27,31,33-35,38,39,41,44,46,48,49]$, legumes $[9,14,30,40]$, fruit [3] and spices [32]. However, the dry grinding method has some drawbacks due to the generation of heat, which causes damage to physical and functional qualities of resulting powders, such as nutrient components and aroma [52-54].

The dry grinding of rice using a roller mill, hammer mill and pin mill has been investigated in the study of Ngamnikom and Songsermpong [5]. The maximum temperature of samples after dry grinding increased up to $46.5^{\circ} \mathrm{C}$, whereas wet and freeze grinding increased up to $39.5^{\circ} \mathrm{C}$ and $25.2^{\circ} \mathrm{C}$, respectively. Both the pin mill and hammer mill generated more heat than the roller mill; however, damage to the starch content was the highest in the dry grinding processes, and there were no significant differences in damaged starch content among the grinding machines. In the semi-dry/wet grinding process, the powder properties were intermediate to dry and wet ground powder with regard to damaged starch amount, viscosity, particle size, etc. The higher initial moisture content of the sample of the semi-dry/wet grinding method produced powder of better physical and functional quality. The rice powder resulting from the semi-dry/wet grinding method had quality attributes in whiteness and damaged starch content that improved as the moisture content increased [53]. However, it had a lower grinding efficiency than the dry grinding method $[39,54]$.

\subsubsection{Wet Grinding}

Wet grinding is a conventional process to prepare food powder, and it includes five successive processes: hydration (also known as soaking), adding additional water during grinding, filtering, drying and sieving. Wet grinding is generally conducted after complete hydration that enables the food materials to soften. Generally, the moisture content of the soaking curve reaches equilibrium [5]. Wet grinding is advantageous for the quality attributes of the end product. Rice powder showed the highest whiteness, and the lowest damaged starch content in the study of Tong et al. [53]. The better starch quality of rice after wet grinding was also observed in the studies of Asmeda and Noorlaila [55] and Leewatchararongjaroen and Anuntagool [56]. It was observed that the pre-soaking of soybean is useful in the size reduction and the separation of the fiber from other constituents generated during the grinding process, besides reducing the grinding time and energy [26]. The drawbacks of this process are that it requires the use of many equipment and human resources. In light of the costs associated with product loss, an alternative method is needed for the high water consumption, high energy consumption and treatment of wastewater [5]. In addition, this method induces changes in both the chemical and the physical property [5]. For instance, off-flavors are produced during wet grinding of soybean, a pretreatment process for soymilk. The wet grinding provides favorable circumstances to accelerate the chemical reactions, such as lipid oxidation presented in water and air catalyzed by lipoxygenase. Therefore, the cost of operation, soaking time and the materials' characteristics have to be considered for this method. 


\subsection{Particle Shape and Size Distribution}

After grinding, the particles of food powder have various sizes and shapes. In food processing, mixing and flow operations can be affected by the sizes and shapes of the particles [57]. Therefore, in food processing-related tasks, such as the manufacturing and transportation of products, it is necessary to determine and to understand the characteristics of particles [51]. Especially, the particle size determines the quality of food products. For example, uniform dispersion of particles in food products showed an acceptable and desirable consistency [58].

The grinding process utilizing shear forces or attrition plays a major role in producing fine food particles [59]. According to Barbosa-Cánovas [4], three main particle attrition mechanisms have been studied: shattering, chipping and erosion (Figure 2). These mechanisms are governed by the failure modes respectively, brittle, semi-brittle and ductile [60]. Medium-sized particles are produced by shattering, whereas the smaller particles are produced by erosion. Usually soft materials are subjected to ductile failure. The initial moisture content of food materials might be closely related to these attrition mechanisms.

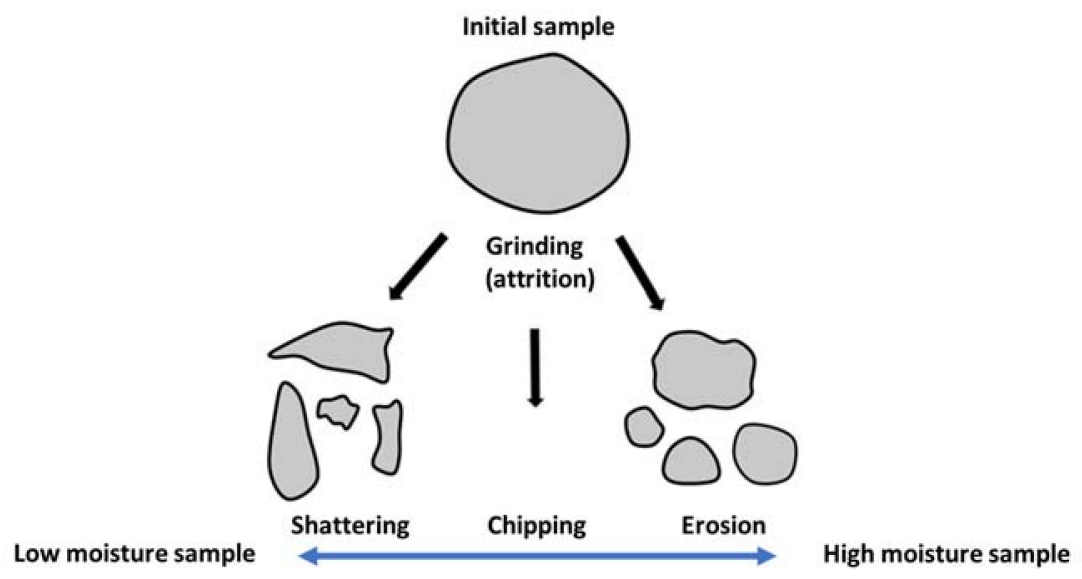

Figure 2. The main size reduction mechanisms of particle attrition and the relationship with moisture content of initial sample.

Particle shape and size distribution are closely related to a material's hardness. After grinding, the particle shape is more irregular for the food materials with high moisture content due to the brittle breakdown characteristics. For the dry and wet grinding of rice, the particle shape showed sharp breakage angles after dry grinding, and round and smooth surfaces were observed in the particles subjected to wet grinding [5].

For the powder resulting from dry and semi-dry/wet grindings, the increase of initial moisture content increased the average particle size and the large particle fraction $[8-10,27,32,35,36,42,44,45]$. When the moisture content is low, the food material is brittle, and breakdown by force is applied. However, an increase in a material's plasticity is observed when moisture content increases. In the study by Dziki [27], wheat kernel showed many cracks when the moisture amount was lesser than $16 \%$, whereas the cracks were not observed when the moisture content was above $16 \%$. Similar results have been observed in the grinding of black soybean [14] and pea [40]. Alternatively, opposite results are found by the wet grinding process. On the materials with the equilibrium moisture, the softening effect by soaking in water resulted in a smaller mean particle size and fine particle fractions. The finest mean particle size after wet grinding was observed in grinding of rice compared to the particles resulting from dry and semi-dry/wet grinding $[45,55]$. 


\section{Effect of Moisture Content on the Flow Properties of Powder}

The bulk properties of powder can be influenced by the moisture content of the food powders [61]. The bulk properties of food powder, including bulk density and flowability, are influenced by the external morphological properties of each particle and the physical and chemical properties of the materials. Most free-flowing dry powders typically adsorb moisture during transportation and storage at high relative humidity environments [62]. The caking mechanism is caused by inappropriate temperature and humidity conditions. As shown in Figure 3, the moisture in the basundi mix accelerates agglomeration because of the strong interlocking force associated with the inter-particle liquid bridges [61]. The particle bridging that resulted in stickiness or caking with increase in moisture content caused the decreased flow-related properties.

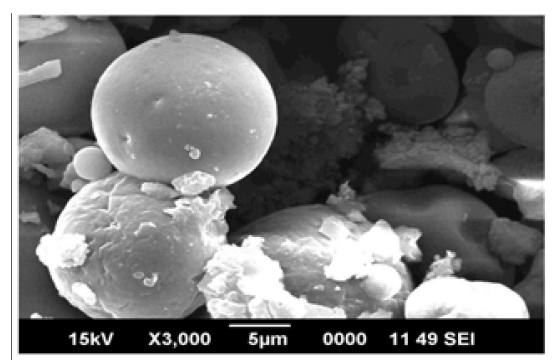

(a)

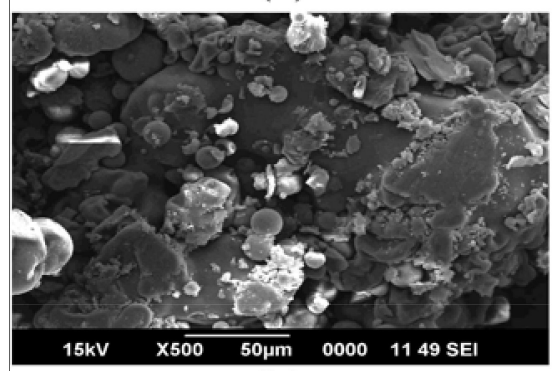

(b)

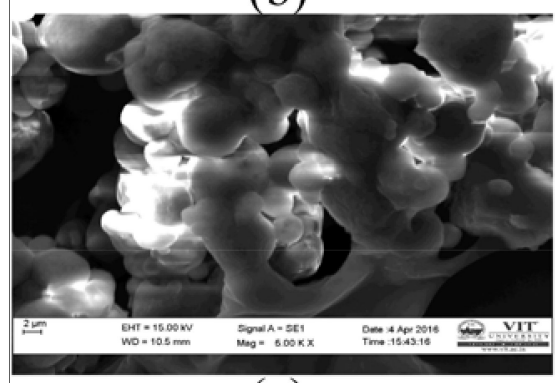

(c)

Figure 3. Influence of moisture content on morphology of basundi mix (a) at 3\% moisture content $(3000 \times),($ b) at $9 \%$ moisture content $(500 \times)$ and $(\mathbf{c})$ at $9 \%$ moisture content $(5000 \times)$ (Mitra et al. [61], with permission).

Various research relating to the flow behavior of food powder has been carried out to understand the effect of the moisture content on the powder flowability. Teunou and Fitzpatrick [63] investigated the flow behavior with different surrounding air temperature and relative humidity. The flowability of wheat powder was significantly influenced by the relative humidity of the powders. Teunou et al. [17] also reported that high moisture content of the food powders, such as wheat powder, milk powder, tea powder and whey-permeate powder, resulted in a decrease in powder flowability caused by the cohesion between the powder particles by water. According to Fitzpatrick et al. [18], when designing a hopper for food powders with higher moisture content, a large hopper opening size is required because food powders 
with higher moisture content displayed poor flowability. Landillon et al. [64] demonstrated the cohesive properties and flowability for the wheat powders. They found that the particles of wheat powders with low moisture content significantly contributed to flowability and cohesive properties. Because the water molecules act as a plasticizer on the powder components, the moisture contents affect the flowability and the cohesion properties of the powder. Opaliński et al. [19] also explored the fact that the high level of moisture content resulted in increasing mechanical strength of the powder bed and poor powder flowability, particularly in a bad pattern of flow out of silos. Recently, Opaliński et al. [65] observed that the moisture in food powders can act as a plasticizing agent for hygroscopic food powders such as semolina and coarse wheat powder, but it can also act as a lubricating factor for non-hygroscopic particles when flowing. In addition, the work of Juarez-Enriquez et al. [62] found that hygroscopic food powders, especially pectin powder, modified its flowability from free-flow to cohesive powder as the water content of the powders increased due to the increase particles interactions by formation of liquid-bridges.

\section{Recent Grinding Methods and Powder Flowability Measurement Methods}

In a number of recent studies, the grinding methods used to make food powders with improved quality have been examined. Especially, it was found that cryogenic grinding performs better than any other method because this technology can maintain a low temperature, using liquid nitrogen at $-196^{\circ} \mathrm{C}$, and the heat generated during grinding is absorbed [66]. Cryogenic grinding of food materials has been used mainly for the process of grinding spices [67-75]. Singh and Goswami [75], as early as 1999, designed and developed a cryogenic grinding system that has been used for various spices, such as cumin seed [76] and clove [77]. Grinding characteristics of fenugreek resulted in an energy requirement that did not alter with moisture in cryogenic grinding compared with ambient grinding conditions [72]. In the research of Meghwal et al. [78], cryogenically ground black pepper powder with different levels of moisture content was studied. Through conventional grinding methods, black pepper powder with high moisture content was stickier than when the cryogenic grinding method was used, because in the latter method, the material had become brittle.

Another of the new approaches to studying the grinding process and powder flowability is a numerical method, such as the discrete element method (DEM), which is applied to design mechanical behavior and simulate particle flow. The DEM has been used by many researchers to simulate milling processes of food materials such as black pepper seeds [79,80]. In addition, the ring shear cell test for measuring flowability of powder is also simulated using DEM [22,63]. This approach can be applied to predict and analyze the flowability and the flow properties using various particle properties, which are influenced by the moisture content of the food materials [63].

\section{Conclusions}

An overview of the theoretical and experimental researches into the effects of moisture content on the process of grinding food materials was presented. Grinding is commonly used as a fundamental unit operation for creating food powders. The purpose of grinding is to produce smaller particles from larger ones, and this size reduction may then assist other processes. The grinding kinetics and energy can be calculated using models. After grinding, it is important to sample particle size and distribution, since these determine the powder properties. Food materials with low moisture content have high grinding efficiency, since such materials are more brittle. In addition, an increase in moisture content causes an increase in plasticity, which determines ductile failure grinding behavior that leads to an increase in difficulty of grinding. Powder flow properties are also affected by moisture content. Moisture content is a crucial aspect in food powders as it is associated with increased cohesiveness, due in part to inter-particle liquid bridges. Controlling moisture content before and after the food grinding process is extremely important in achieving higher energy efficiencies in the food industry. Furthermore, recent and novel techniques to evaluate the ground powders with improved quality using cryogenic grinding and to measure powder flowability using DEM can be adopted in practice, depending on the moisture content of the materials. 
Author Contributions: Writing-Original Draft Preparation, H.J.; Conceptualization, Y.J.L.; Supervision, W.B.Y.

Acknowledgments: This study has been carried out with the support of a research grant from Kangwon National University in 2016.

Conflicts of Interest: The authors declare no conflicts of interest.

\section{References}

1. Murrieta-Pazos, I.; Gaiani, C.; Galet, L.; Calvet, R.; Cuq, B.; Scher, J. Food powders: Surface and form characterization revisited. J. Food Eng. 2012, 112, 1-21. [CrossRef]

2. Kamdem, A.T.K.; Hardy, J. Influence of various conditions on meat grinding characteristics. J. Food Eng. 1995, 25, 179-196. [CrossRef]

3. Djantou, E.B.; Mbofung, C.M.; Scher, J.; Desobry, S. A modelling approach to determine the effect of pre-treatment on the grinding ability of dried mangoes for powder production (Mangifera indica var Kent). J. Food Eng. 2007, 80, 668-677. [CrossRef]

4. Barbosa-Cánovas, G.V.; Ortega-Rivas, E.; Juliano, P.; Yan, H. Food Powders: Physical Properties, Processing, and Functionality; Springer: New York, NY, USA, 2005; pp. 157-173. ISBN 978-0-306-47806-2.

5. Ngamnikom, P.; Songsermpong, S. The effects of freeze, dry, and wet grinding processes on rice flour properties and their energy consumption. J. Food Eng. 2011, 104, 632-638. [CrossRef]

6. Walde, S.G.; Balaswamy, K.; Velu, V.; Rao, D.G. Microwave drying and grinding characteristics of wheat (Triticum aestivum). J. Food Eng. 2002, 55, 271-276. [CrossRef]

7. Muhamad, I.I.; Campbell, G.M. Effects of kernel hardness and moisture content on wheat breakage in the single kernel characterisation system. Innov. Food Sci. Emerg. Technol. 2004, 5, 119-125. [CrossRef]

8. Dziki, D. Effect of preliminary grinding of the wheat grain on the pulverizing process. J. Food Eng. 2011, 104, 585-591. [CrossRef]

9. Lee, Y.J.; Lee, M.G.; Yoon, W.B. Effect of seed moisture content on the grinding kinetics, yield and quality of soybean oil. J. Food Eng. 2013, 119, 758-764. [CrossRef]

10. Moon, J.H.; Yoon, W.B. Effect of moisture content and particle size on grinding kinetics and flowability of balloon flower (Platycodon grandiflorum). Food Sci. Biotechnol. 2017, 1-10. [CrossRef]

11. Lee, Y.J.; Yoon, W.B. Flow behavior and hopper design for black soybean powders by particle size. J. Food Eng. 2015, 144, 10-19. [CrossRef]

12. Park, H.W.; Yoon, W.B. Measuring ring tensile stress and strain of surimi gels using a novel ring tensile test with image analysis. J. Food Eng. 2015, 163, 9-16. [CrossRef]

13. Rozalli, N.H.M.; Chin, N.L.; Yusof, Y.A. Grinding characteristics of Asian originated peanuts (Arachishypogaea L.) and specific energy consumption during ultra-high speed grinding for natural peanut butter production. J. Food Eng. 2015, 152, 1-7. [CrossRef]

14. Lee, Y.J.; Yoo, J.S.; Yoon, W.B. Grinding characteristics of black soybeans (Glycine max) at varied moisture contents: Particle size, energy consumption, and grinding kinetics. Int. J. Food Eng. 2014, 10, 347-356. [CrossRef]

15. Henderson, S.M.; Perry, R.L. Agricultural Process Engineering; University of California: Oakland, CA, USA, 1970.

16. Bond, F.C. Crushing and grinding calculations. Br. Chem. Eng. 1961, 6, 378-385.

17. Teunou, E.; Fitzpatrick, J.J.; Synnott, E.C. Characterisation of food powder flowability. J. Food Eng. 1999, 39, 31-37. [CrossRef]

18. Fitzpatrick, J.J.; Barringer, S.A.; Iqbal, T. Flow property measurement of food powders and sensitivity of Jenike's hopper design methodology to the measured values. J. Food Eng. 2004, 61, 399-405. [CrossRef]

19. Opaliński, I.; Chutkowski, M.; Stasiak, M. Characterizing moist food-powder flowability using a Jenike shear-tester. J. Food Eng. 2012, 108, 51-58. [CrossRef]

20. Fadeyibi, A.; Osunde, Z.D.; Agidi, G.; Evans, E.C. Flow and strength properties of cassava and yam starch-glycerol composites essential in the design of handling equipment for granular solids. J. Food Eng. 2014, 129, 38-46. [CrossRef]

21. Crowley, S.V.; Gazi, I.; Kelly, A.L.; Huppertz, T.; O’Mahony, J.A. Influence of protein concentration on the physical characteristics and flow properties of milk protein concentrate powders. J. Food Eng. 2014, 135, 31-38. [CrossRef] 
22. Falke, T.; de Payrebrune, K.M.; Kirchhof, S.; Kühnel, L.; Kühnel, R.; Mütze, T.; Kröger, M. An alternative DEM parameter identification procedure based on experimental investigation: A case study of a ring shear cell. Powder Technol. 2018, 328, 227-234. [CrossRef]

23. Caparino, O.A.; Nindo, C.I.; Tang, J.; Sablani, S.S. Rheological measurements for characterizing sticky point temperature of selected fruit powders: An experimental investigation. J. Food Eng. 2017, 195, 61-72. [CrossRef]

24. Saad, M.; Sadoudi, A.; Rondet, E.; Cuq, B. Morphological characterization of wheat powders, how to characterize the shape of particles? J. Food Eng. 2011, 102, 293-301. [CrossRef]

25. Fu, X.; Huck, D.; Makein, L.; Armstrong, B.; Willen, U.; Freeman, T. Effect of particle shape and size on flow properties of lactose powders. Particuology 2012, 10, 203-208. [CrossRef]

26. Pan, Z.; Tangratanavalee, W. Characteristics of soybeans as affected by soaking conditions. LWT-Food Sci. Technol. 2003, 36, 143-151. [CrossRef]

27. Dziki, D. The crushing of wheat kernels and its consequence on the grinding process. Powder Technol. 2008, 185, 181-186. [CrossRef]

28. Djantou, E.B.; Mbofung, C.M.F.; Scher, J.; Phambu, N.; Morael, J.D. Alternation drying and grinding (ADG) technique: A novel approach for producing ripe mango powder. LWT-Food Sci. Technol. 2011, 44, 1585-1590. [CrossRef]

29. Jagtap, P.S.; Subramanian, R.; Singh, V. Influence of soaking on crushing strength of raw and parboiled rice. Int. J. Food Prop. 2008, 11, 127-136. [CrossRef]

30. Laskowski, J.; Lysiak, G. Use of compression behaviour of legume seeds in view of impact grinding prediction. Powder Technol. 1999, 105, 83-88. [CrossRef]

31. Kiryluk, J.; Kawka, A.; Gasiorowski, H.; Chalcarz, A.; Anioła, J. Milling of barley to obtain $\beta$-glucan enriched products. Nahr. Food 2000, 44, 238-241. [CrossRef]

32. Balasubramanian, S.; Kumar, R.; Singh, K.K.; Zachariah, T.J.; Vikram, V. Size reduction characteristics of black pepper. J. Spices Aromat. Crop. 2013, 22, 138-147.

33. Dabbour, M.I.; Bahnasawy, A.; Ali, S.; El-Haddad, Z. Grinding parameters and their effects on the quality of corn for feed processing. J. Food Process. Technol. 2015, 6, 1-8. [CrossRef]

34. Probst, K.V.; Ambrose, R.P.K.; Pinto, R.L.; Bali, R.; Krishnakumar, P.; Ileleji, K.E. The effect of moisture content on the grinding performance of corn and corncobs by hammermilling. Trans. ASABE 2013, 56, 1025-1033. [CrossRef]

35. Deng, L.; Manthey, F.A. Laboratory-scale milling of whole-durum flour quality: Effect of mill configuration and seed conditioning. J. Sci. Food Agric. 2017, 97, 3141-3150. [CrossRef] [PubMed]

36. Balasubramanian, S.; Rajkumar, R.; Singh, K.K. Determination of grinding parameters of fenugreek seed. J. Spices Aromat. Crop. 2017, 26, 16-26. [CrossRef]

37. Schorno, A.L.; Manthey, F.A.; Hall, C.A. Effect of seed moisture content on flaxseed (Linum usitatissimum L.) milling and milled product characteristics. J. Sci. Food Agric. 2009, 89, 2317-2322. [CrossRef]

38. Oduro-Yeboah, C.; Mestres, C.; Amoa-Awua, W.; Fliedel, G.; Durand, N.; Matignon, B.; Michodjehoun, V.L.; Saalia, F.K.; Sakyi-Dawson, E.; Abbey, L. Steeping time and dough fermentation affect the milling behaviour and quality of white kenkey(nsiho), a sour stiff dumpling prepared from dehulled maize grains. J. Cereal Sci. 2016, 69, 377-382. [CrossRef]

39. Velu, V.; Nagender, A.; Rao, P.G.P.; Rao, D.G. Dry milling characteristics of microwave dried maize grains (Zea mays L.). J. Food Eng. 2006, 74, 30-36. [CrossRef]

40. Dijkink, B.H.; Langelaan, H.C. Milling properties of peas in relation to texture analysis. Part II. Effect of pea genotype. J. Food Eng. 2002, 51, 105-111. [CrossRef]

41. Balasubramanian, S.; Sharma, R.; Kumar, S.R.V. Effect of Moisture Content and Feed Rate on Size Reduction of Pearl Millet. J. Food Sci. Eng. 2011, 1, 93-99.

42. Jha, S.N.; Sharma, R. Physical, gravimetric and functional characterization of various milling fractions of popped gorgon nut (Euryale ferox). J. Food Sci. Technol. 2010, 47, 564-570. [CrossRef] [PubMed]

43. Dziki, D.; Tomiło, J.; Różyło, R.; Laskowski, J.; Gawlik-dziki, U. Influence of moisture content on the mechanical properties and grinding energy requirements of dried quince (Cydonia Oblonga Miller). Teka. Comm. Mot. Energ. Agric. 2012, 12, 35-39.

44. Hassoon, W.H.; Dziki, D. The effect of seed moisture and temperature on grinding characteristics of quinoa (Chenopodium quinoa Willd.). BIO Web Conf. 2018, 1006, 1-4. [CrossRef] 
45. Chiang, P.Y.; Yeh, A.I. Effect of soaking on wet-milling of rice. J. Cereal Sci. 2002, 35, 85-94. [CrossRef]

46. Beta, T.; Rooney, L.W.; Taylor, J.R.N. Effect of chemical conditioning on the milling of high-tannin sorghum. J. Sci. Food Agric. 2000, 80, 2216-2222. [CrossRef]

47. Dennett, A.L.; Trethowan, R.M. Milling efficiency of triticale grain for commercial flour production. J. Cereal Sci. 2013, 57, 527-530. [CrossRef]

48. Doblado-Maldonado, A.F.; Flores, R.A.; Rose, D.J. Low moisture milling of wheat for quality testing of wholegrain flour. J. Cereal Sci. 2013, 58, 420-423. [CrossRef]

49. Edwards, M.A.; Osborne, B.G.; Henry, R.J. Investigation of the effect of conditioning on the fracture of hard and soft wheat grain by the single-kernel characterization system: A comparison with roller milling. J. Cereal Sci. 2007, 46, 64-74. [CrossRef]

50. Badmus, A.A.; Raji, A.O.; Akinoso, R. Effect of process parameters on work index, milling efficiency and some technological properties of yam flour using attrition mill. Food Bioprocess Technol. 2013, 6, 160-168. [CrossRef]

51. McCabe, W.L.; Warren, L.; Smith, J.C.; Harriot, P. Unit Operations of Chemical Engineering, 5th ed.; McGraw-Hill: New York, NY, USA, 1993; ISBN 978-0072848236.

52. Murthy, C.T.; Rani, M.; Rao, P.N.S. Optimal grinding characteristics of black pepper for essential oil yield. J. Food Process Eng. 2007, 22, 161-173. [CrossRef]

53. Tong, L.T.; Gao, X.; Lin, L.; Liu, Y.; Zhong, K.; Liu, L.; Zhou, X.; Wang, L.; Zhou, S. Effects of semidry flour milling on the quality attributes of rice flour and rice noodles in China. J. Cereal Sci. 2015, 62, 45-49. [CrossRef]

54. Tong, L.T.; Gao, X.; Zhou, X.; Zhong, K.; Liu, L.; Wang, L.; Zhou, S. Milling of glutinous rice by semidry method to produce sweet dumplings. J. Food Process Eng. 2016, 39, 330-334. [CrossRef]

55. Asmeda, R.; Noorlaila, A.; Norziah, M.H. Effects of different grinding methods on chemical and functional properties of MR211 rice flour. Int. J. Food Eng. 2015, 1, 111-114. [CrossRef]

56. Leewatchararongjaroen, J.; Anuntagool, J. Effects of dry-milling and wet-milling on chemical, physical and gelatinization properties of rice flour. Rice Sci. 2016, 23, 274-281. [CrossRef]

57. Devaux, M.F.; Robert, P.; Melcion, J.P.; de Monredon, L.D. Particle size analysis of bulk powders using mathematical morphology. Powder Technol. 1997, 90, 141-147. [CrossRef]

58. Singh, R.; Mangaraj, S.; Kulkarni, S.D. Particle-size analysis of tomato powder. J. Food Process. Preserv. 2006, 30, 87-98. [CrossRef]

59. Bayram, M.; Öner, M.D. Bulgur milling using roller, double disc and vertical disc mills. J. Food Eng. 2007, 79, 181-187. [CrossRef]

60. Gotoh, K.; Masuda, H.; Higashitani, K. Powder Technology Handbook, 2nd ed.; CRC Press: Boca Raton, FL, USA, 1997; ISBN 978-0824700157.

61. Mitra, H.; Pushpadass, H.A.; Franklin, M.E.E.; Ambrose, R.P.K.; Ghoroi, C.; Battula, S.N. Influence of moisture content on the flow properties of basundi mix. Powder Technol. 2017, 312, 133-143. [CrossRef]

62. Juarez-Enriquez, E.; Olivas, G.I.; Zamudio-Flores, P.B.; Ortega-Rivas, E.; Perez-Vega, S.; Sepulveda, D.R. Effect of water content on the flowability of hygroscopic powders. J. Food Eng. 2017, 205, 12-17. [CrossRef]

63. Teunou, E.; Fitzpatrick, J.J. Effect of relative humidity and temperature on food powder flowability. J. Food Eng. 1999, 42, 109-116. [CrossRef]

64. Landillon, V.; Cassan, D.; Morel, M.H.; Cuq, B. Flowability, cohesive, and granulation properties of wheat powders. J. Food Eng. 2008, 86, 178-193. [CrossRef]

65. Opaliński, I.; Chutkowski, M.; Hassanpour, A. Rheology of moist food powders as affected by moisture content. Powder Technol. 2016, 294, 315-322. [CrossRef]

66. Murthy, C.T.; Bhattacharya, S. Cryogenic grinding of black pepper. J. Food Eng. 2008, 85, 18-28. [CrossRef]

67. Goswami, T.K.; Singh, M. Role of feed rate and temperature in attrition grinding of cumin. J. Food Eng. 2003, 59, 285-290. [CrossRef]

68. Liu, H.; Zeng, F.; Wang, Q.; Ou, S.; Tan, L.; Gu, F. The effect of cryogenic grinding and hammer milling on the flavour quality of ground pepper (Piper nigrum L.). Food Chem. 2013, 141, 3402-3408. [CrossRef] [PubMed]

69. Meghwal, M.; Goswami, T.K. Ambient and cryogenic grinding of fenugreek and flow characterization of its powder. J. Food Process Eng. 2013, 36, 548-557. [CrossRef]

70. Meghwal, M.; Goswami, T.K. Comparative study on ambient and cryogenic grinding of fenugreek and black pepper seeds using rotor, ball, hammer and Pin mill. Powder Technol. 2014, 267, 245-255. [CrossRef] 
71. Sharma, L.K.; Agarwal, D.; Sharma, Y.; Rathore, S.S.; Saxena, S.N. Cryogenic grinding technology enhances volatile oil, oleoresin and antioxidant activity of cumin (Cuminum cyminum L.). Int. J. Seed Spices 2014, 4, $68-72$.

72. Barnwal, P.; Singh, K.K.; Mohite, A.; Sharma, A.; Saxena, S.N. Influence of cryogenic and ambient grinding on grinding characteristics of fenugreek powder: A comparative study. J. Food Process. Preserv. 2015, 39, 1243-1250. [CrossRef]

73. Barnwal, P.; Kumar, P.; Singh, K.K.; Mohite, A.M. Selected engineering properties of cryogenic and ambient ground black pepper. J. Food Process. Preserv. 2017, 41. [CrossRef]

74. Ghodki, B.M.; Goswami, T.K. Effect of grinding temperatures on particle and physicochemical characteristics of black pepper powder. Powder Technol. 2016, 299, 168-177. [CrossRef]

75. Singh, K.K.; Goswami, T.K. Design of a cryogenic grinding system for spices. J. Food Eng. 1999, 39, 359-368. [CrossRef]

76. Singh, K.K.; Goswami, T.K. Studies on cryogenic grinding of cumin seed. J. Food Process Eng. 1999, 22, 175-190. [CrossRef]

77. Singh, K.K.; Goswami, T.K. Cryogenic grinding of cloves. J. Food Process. Preserv. 2000, 24, 57-71. [CrossRef]

78. Meghwal, M.; Goswami, T.K. Flow characterization of ambiently and cryogenically ground black pepper (Piper nigrum) powder as a function of varying moisture content. J. Food Process Eng. 2017, 40. [CrossRef]

79. Ghodki, B.M.; Goswami, T.K. DEM simulation of flow of black pepper seeds in cryogenic grinding system. J. Food Eng. 2017, 196, 36-51. [CrossRef]

80. Ghodki, B.M.; Kumar, C.K.; Goswami, T.K. Modeling breakage and motion of black pepper seeds in cryogenic mill. Adv. Powder Technol. 2018, 29, 1055-1071. [CrossRef]

(C) 2018 by the authors. Licensee MDPI, Basel, Switzerland. This article is an open access article distributed under the terms and conditions of the Creative Commons Attribution (CC BY) license (http:/ / creativecommons.org/licenses/by/4.0/). 